\title{
PEMANFAATAN GOOGLE CLASSROOM SEBAGAI MEDIA PEMBELAJARAN INTERAKTIF DI TENGAH DAMPAK PENYAKIT VIRUS CORONA 19 BAGI PENGAJAR
}

\section{UTILIZING GOOGLE CLASSROOM AS AN INTERACTIVE LEARNING MEDIUM IN THE MIDDLE OF IMPACT CORONA VIRUS DIESEAS 19 FOR TEACHERS}

\author{
Fauzan Asrin ${ }^{1 *}$, Thamrin 2), Anas Sholikhin ${ }^{3)}$, Rugayah ${ }^{4)}$ \\ 1) Universitas Nahdlatul Ulama Kalimantan Barat \\ 2,4) Universitas Tanjungpura, Pontianak \\ ${ }^{3}$ Badan Penelitian dan Pengembangan Provinsi Kalimantan Barat, Pontianak \\ *e-mail: fauzan.asrin@unukalbar.ac.id
}

Submit : 29 April 2020 ; Revisi :28 Juli 2020 ; Terbit : 29 Juli 2020

\begin{abstract}
The Corona Virus Diseas 19 (COVID 19) pandemic has become a global health problem today. Almost the whole world feels the effects of this deadly disease, either in the economic, governmental, and educational sectors. The Republic of Indonesia has endeavored to invite all educational institutions starting from the elementary schools to the tertiary education to study at home. It is deemed the appropriate government policy at this time to make the students always active with online education services. The aim is to break the chain of massive spread of the corona virus in the education areas. One solution for online learning at home is using Google classroom as an interactive learning media. It makes the teachers and students easy to do the teaching and learning process through the use of information and communication technology. Google classroom is currently so effective and efficient in space and time, that the teachers can provide the students with online-based teaching materials, ether in texts, images, audios, or videos. Such teaching materials enable the students to repeat the teaching materials distributed by the teacher continuously.
\end{abstract}

Keywords: Corona Virus Diseas 19, Google Classrom, E-Learning, Teacher

\begin{abstract}
ABSTRAK
Pandemi Wabah Virus Corona 19 (COVID 19) menjadi permasalahan kesehatan dunia pada saat ini. Hampir seluruh dunia merasakan dampak wabah penyakit mematikan ini, baik disektor ekonomi, pemerintahan, pendidikan dan lain sebagainya. Negara Republik Indonesia telah berupaya untuk mengajak seluruh institusi bidang pendidikan belajar di rumah. Karena merupakan kebijakan pemerintah yang tepat pada saat ini. Mulai dari sekolah dasar sampai dengan perguruan tinggi, agar selalu aktif memberikan layanan pendidikan secara daring bagi anak bangsa di tengah wabah virus corona yang melanda Republik Indonesia. Tujuannya adalah memutus mata rantai penyebaran secara masif virus corona di area pendidikan. Salah satu solusi belajar dirumah secara daring adalah menggunakan google classroom sebagai media pembelajaran interaktif berbasis e-learning yang memudahkan pengajar dan peserta didik melakukan proses belajar mengajar di rumah untuk menunjang pembelajaran berbasis teknologi informasi dan komunikasi. Pemanfaatan google classroom saat ini sangat efektif dan efisien yang tidak terbatas oleh ruang dan waktu. Pengajar dapat memberikan bahan ajar secara online, baik berupa teks, gambar, audio, maupun video kepada peserta didik. Manfaat yang didapat peserta didik adalah peserta didik dapat mengulang materi yang telah dibagikan oleh pengajar secara terus menerus.
\end{abstract}

Kata kunci: Virus Corona 19, Google Classroom, E-Learning, Pengajar. 


\section{PENDAHULUAN}

Akhir-akhir ini dunia dilanda virus baru yang diidentifikasi berasal dari Wuhan, China pada Desember 2019. Orang yang telah terpapar dengan virus ini memiliki gejala seperti demam di atas suhu normal manusia atau di atas suhu $38^{\circ} \mathrm{C}$. Gangguan pernafasan seperti batuk, sesak nafas serta dengan gejala lainnya seperti gangguan tenggorokan, mual, dan pilek. Ancaman terburuk dari virus ini adalah dapat mengakibatkan seseorang meninggal dunia apabila terjangkit. Organisasi Kesehatan Dunia (World Health Organization) menyatakan bahwa virus ini adalah pandemik. Suatu penyakit dikatakan pandemik apabila sudah menyebar secara cepat ke seluruh dunia dengan tingkat infeksi yang tinggi. Saat ini dunia berada pada Darurat Kesehatan Internasional.

Di Indonesia sendiri penyebaran wabah virus corona sangat masif sehingga salah satu sektor yang sangat penting di Indonesia yaitu, pendidikan diatur secara signifikan agar tidak terjadi ketertinggalan pembelajaran. Tujuan utamanya adalah untuk memutus rantai penyebaran virus corona. Penyebaran virus corona didasarkan pada kontak fisik yang sangat dekat akibat terjadinya kerumunan masa yang banyak pada suatu tempat. Pemerintah Indonesia, lembaga, dan badan yang terkait berupaya untuk mencegah penyebaran virus corona dengan mendorong masyarakat untuk bekerja di rumah, beribadah di rumah, dan belajar di rumah. $\mathrm{Di}$ tengah dampak virus corona di Indonesia, sektor pendidikan mulai dari tingkat Sekolah Dasar sampai dengan Pendididkan Tinggi diupayakan tidak terputus pembelajaran. Pendidikan merupakan bagian dari sistem kehidupan di masyarakat yang tidak dapat dilepaskan dari perkembangan dan perubahan yang tejadi di masyarakat itu sendiri (Soni, dkk, 2018). Undang-undang Nomor 20 Tahun 2003 tentang pendidikan nasional (sisdiknas) menyebutkan bahwa pendidikan adalah usaha yang dasar dan terencana untuk mewujudkan suasana belajar dan proses pembelajaran agar peserta didik secara aktif mengembangkan potensi dirinya untuk memiliki kekuatan spiritual agama, pengendalian diri kepribadian, kecerdasan, akhlak mulia, serta ketrampilan yang diperlukan dirinya, masyarakat, bangsa, dan negara. Pembelajaran berbasis teknologi telah dilakukan di beberapa negara, yang dikenal dengan istilah Integration of Information, Communication, and Technology (ICT) (Susanti, 2015).

Dengan adanya era teknologi yang semakin berkembang ini maka progam pembelajaran diarahkan untuk bisa memanfaatkan teknologi dengan lebih baik. Salah satu pemanfaatan teknologi saat ini adalah e-Learning dengan menggunakan web untuk mengaksesnya (Nirfayanti \& Nurbaeti, 2019). Di Indonesia, pemanfaatan pembelajaran bebasis daring sudah cukup dikenal. Hal ini terlihat dengan penggunaan platform pembelajaran berbasis daring yang cukup diminati oleh guru seperti penggunaan Edmodo, Schoology dan Google Classroom (El Fauziah et al., 2019)

Pemanfaatan jaringan internet ditandai dengan penggunaan komputer dan telepon genggam. Usia pengguna internet bervariasi, sesuai dengan pemanfaatan masing-masing seperti, media sosial, hiburan, permainan, menjelajah, transaksi jual-beli, dan sebagainya (Wicaksono 
Rachmadyanti, 2016). Di tengah dampak wabah virus corona ini, di Indonesia hampir seluruh sekolah dasar maupun pendidikan tinggi menerapkan media pembelajaran secara daring sesuai dengan arahan dan ajakan pemerintah dengan memanfaatkan jaringan internet.

Google Classroom adalah layanan berbasis internet yang disediakan oleh google sebagai sebuah sistem e-learning. Melalui aplikasi Google Classroom diasumsikan bahwa tujuan pembelajaran akan lebih mudah direalisasikan dan sarat kebermaknaan (Sabran \& Sabara, 2019). Oleh karena itu, penggunaan Google Classroom ini sesungguhnya mempermudah pengajar dalam mengelola pembelajaran dan menyampaikan informasi secara tepat dan akurat kepada peserta didik (Hakim, 2005).

Pembelajaran kolaboratif tatap muka dengan jarak jauh (e-learning berbasis virtual class) dengan google classroom menjadi lebih bermakna karena materi pembelajaran yang disediakan dirancang sedemikian rupa sehingga peserta didik lebih mudah memahaminya (Nurfalah, 2019). Tidak hanya itu, materi pembelajaran yang dibagikan oleh pengajar untuk peserta didik dapat dipelajari kembali kapanpun dan dimanapun ketika ada pembahasan tentang materi yang kurang dimengerti oleh peserta didik.

\section{METODE}

Metode penelitian yang dilakukan adalah studi literatur dan studi pustaka. Pengumpulan data melalui penerapan, pengujian secara langsung, mempelajari literatur e-learning, serta materi yang berkaitan dengan pembelajaran daring dengan memanfaatkan google classroom. Literatur-literatur yang berhubungan dengan pendidikan dikaji lebih mendalam serta dilakukan pengamatan dan penerapan secara langsung untuk melihat efektifitas pemanfaatan e-learning di google classroom.

\section{HASIL DAN PEMBAHASAN}

E-learning adalah pengajaran dan pembelajaran yang didukung dan dikembangkan melalui teknologi dan media digital, dan juga merupakan salah satu bentuk dari konsep distance learning atau belajar jarak jauh (Hakim, 2005). Di masa pandemi ini, elearning menjadi suatu keharusan bagi dunia pendidikan di Indonesia, mulai dari sekolah dasar sampai dengan perguruan tinggi untuk membantu guru dan siswa dalam aktivitas belajar dan mengajarnya.

Manfaat e-learning di masa pandemi dapat dilihat dari 2 sudut pandang yaitu, sudut pandang peserta didik dan sudut pandang pengajar. Dari sudut pandang peserta didik, e-learning memungkinkan fleksibilitas belajar yang tinggi, juga memungkinkan peserta didik berkomunikasi dengan pengajar setiap saat tidak terbatas oleh tempat dan waktu, misalnya, dengan memanfaatkan fasilitas chatting, email atau kolom komentar. Dari sudut pandang pengajar, penggunaan sistem e-learning memungkinkan pengajar untuk lebih mudah melakukan pembaruan materi maupun model pengajaran sesuai dengan tuntutan perkembangan keilmuan, serta dapat dengan efisien mengontrol kegiatan belajar peserta didik.

Aplikasi Google Classroom telah digunakan di dunia barat sebagai penunjang kegiatan pembelajaran dan bentuk dukungan terhadap kemajuan teknologi saat ini (Maharani \& Kartini, 2019). Google Classroom merupakan sebuah aplikasi yang memungkinkan terciptanya ruang kelas di dunia maya. Selain itu, google classroom bisa menjadi sarana 
distribusi tugas, pengiriman tugas bahkan menilai tugas-tugas yang dikumpulkan (Hammi, 2017).

Berdasarkan hasil studi pustaka, penerapan dan pengujian media pembelajaran interaktif dengan menggunakan google classroom di tengah-tengah masa wabah virus corona 19, menurut perspektif pengajar, memberikan kemudahan untuk membagikan dan menyampaikan materi ajar, baik dalam bentuk teks, gambar, audio, maupun video. Pembelajaran secara daring membuat kegiatan belajar mengajar lebih interaktif, efektif, dan efisien antara pengajar dengan peserta didik.

Data tentang hasil belajar mahasiswa dianalisis secara deskriptif. Data hasil belajar secara deskriptif dijabarkan pada tabel distribusi frekuensi sehingga akan terlihat capaian mahasiswa pada skor-skor tertentu. Kriteria yang digunakan untuk menentukan kategori hasil belajar mahasiswa dalam penelitian ini merujuk kepada skala yang digunakan pada perkuliahan di Program Studi Sistem Informasi Universitas Muhammadiyah Pontianak seperti pada Tabel 1 berikut:

Tabel 1. Kriteria Hasil Belajar

\begin{tabular}{ccc}
\hline $\begin{array}{c}\text { Tingkat } \\
\text { Penguasaan }\end{array}$ & HURUF & Keterangan \\
\hline $80-100$ & A & Sangat Baik \\
\hline $70-79$ & B & Baik \\
\hline $60-69$ & C & Cukup \\
\hline $50-59$ & D & Kurang \\
\hline $0-49$ & E & Gagal \\
\hline
\end{tabular}

$\begin{array}{ccr}\text { Untuk } & \text { menguji } & \text { seberapa } \\ \text { manfaatnya } & \text { penggunaan } & \text { google }\end{array}$ classroom terhadap responsif belajar peserta didik di tengah wabah covid 19 dapat dilihat pada gambar berikut:
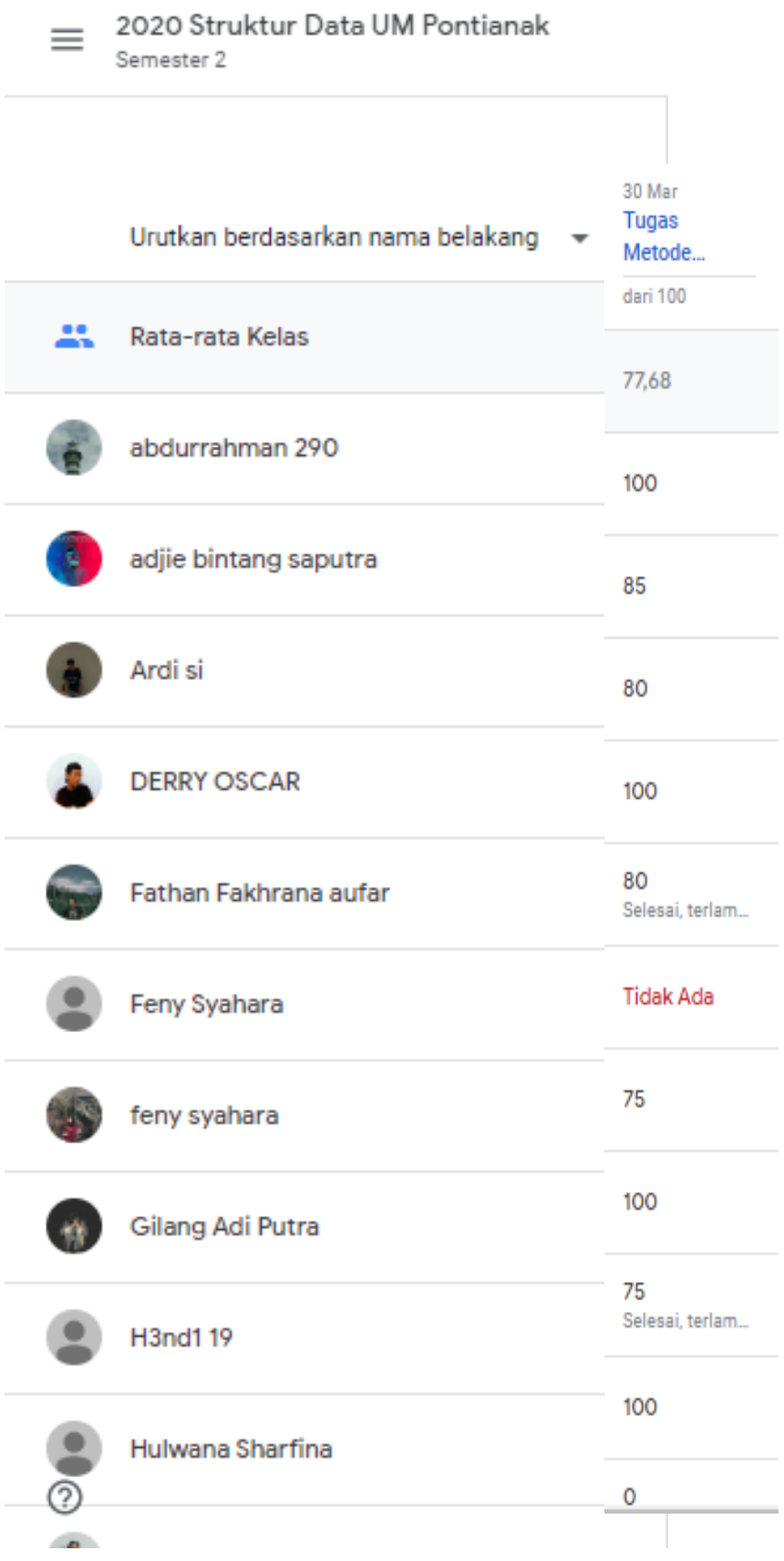

\section{Sumber:}

https://classroom.google.com/u/0/c/NTMOMzExNDIzMjVa/gb/s ort-name

Gambar 1. Tampilan Laman Penilaian pada Google Classroom

Berdasarkan gambar di atas, persentase penilaian mahasiswa di hitung secara otomatis di google 
classroom dengan rerata nilai kelas sebesar $77,68 \%$ dengan rincian total mahasiswa sebanyak 30 orang. Diinventarisasi terdapat 22 orang mahasiswa yang mengumpulkan tugas sedangkan 8 orang lainnya tidak mengumpulkan tugas. Itu artinya $73,3 \%$ tingkat responsif mahasiswa dalam mengerjakan tugas secara daring di google classroom.

Jumlah persentase penerapan pemanfaatan google classroom sebagai media pembelajaran interaktif di tengah dampak penyakit virus corona 19 bagi pengajar dapat di lihat dari sisi keunggulan dan kelemahan pada tabel berikut.

Tabel 2. Hasil Pengujian keunggulan dan kelemahan Google classroom

\begin{tabular}{|c|c|c|}
\hline No & Keunggulan & Keterangan \\
\hline 1 & $\begin{array}{l}\text { Pemanfaatan } \\
\text { Teknologi } \\
\text { Informasi dan } \\
\text { Komunikasi }\end{array}$ & $\begin{array}{l}\text { Pengajar menerapkan } \\
\text { revolusi industri } 4.0\end{array}$ \\
\hline 2 & $\begin{array}{l}\text { Physical } \\
\text { Distancing }\end{array}$ & $\begin{array}{l}\text { Pengajar dan peserta } \\
\text { didik } \\
\text { kebijakan membantu } \\
\text { dalam pemerintah } \\
\text { secara masif Covid19 }\end{array}$ \\
\hline 3 & Bersifat daring & $\begin{array}{l}\text { Pengajar } \\
\text { mejadwalkan pelajaran } \\
\text { tidak terbatas oleh } \\
\text { ruang dan waktu }\end{array}$ \\
\hline 4 & Akses gratis & $\begin{array}{lr}\text { Akses } & \text { gratis } \\
\text { penggunaan } & \text { Google } \\
\text { Classroom } & \end{array}$ \\
\hline 5 & Materi & $\begin{array}{lr}\text { Pengajar } & \text { dapat } \\
\text { memberikan } & \text { Materi, } \\
\text { berupa teks, audio, } \\
\text { video. Peserta didik } \\
\text { dapat mengulang ulang } \\
\text { materi berkali-kali. }\end{array}$ \\
\hline 6 & Tugas & $\begin{array}{l}\text { Pengajar dapat menguji } \\
\text { seberapa faham } \\
\text { peserta didik tentang } \\
\text { materi yang diberikan }\end{array}$ \\
\hline 7 & Tugas/Quiz & $\begin{array}{l}\text { Pengajar } \\
\text { membuat kuis dengan } \\
\text { bantuan google form } \\
\text { yang ada, baik berupa } \\
\text { pilihan ganda maupun }\end{array}$ \\
\hline
\end{tabular}

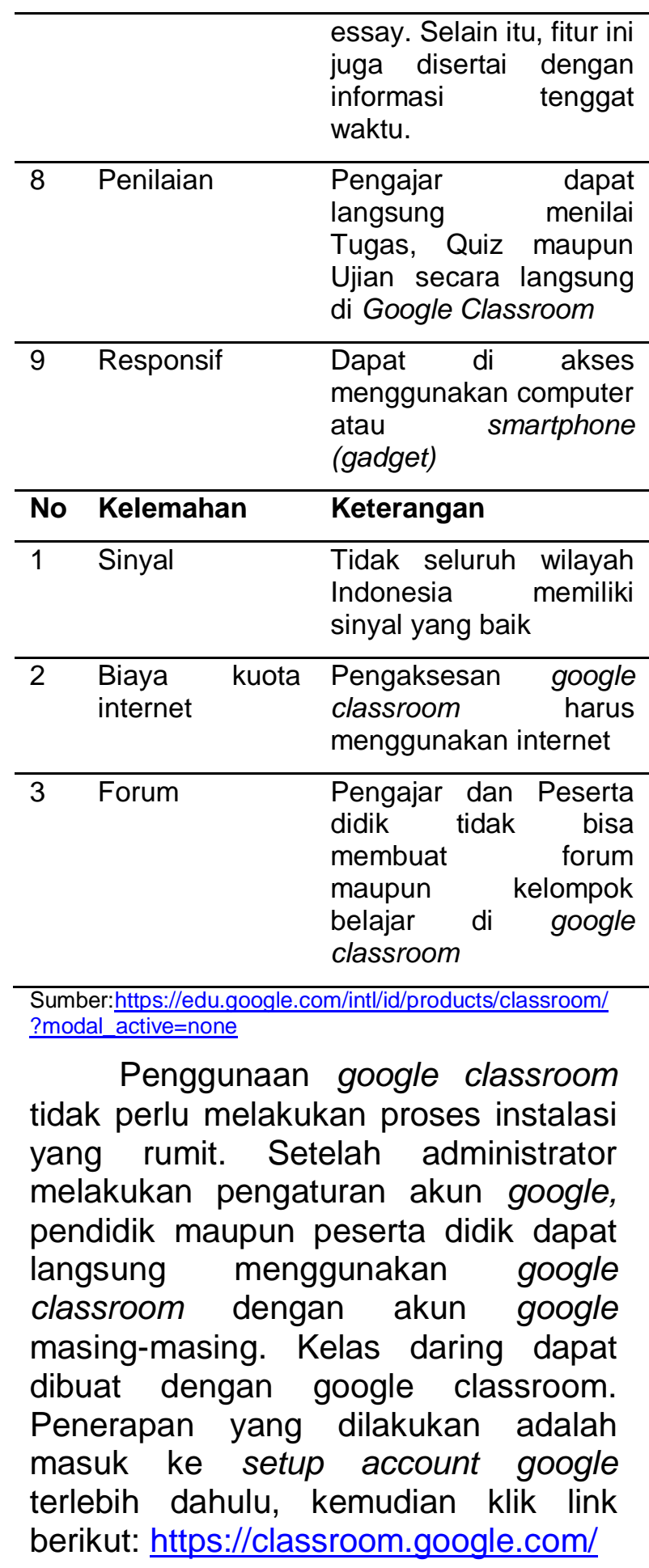




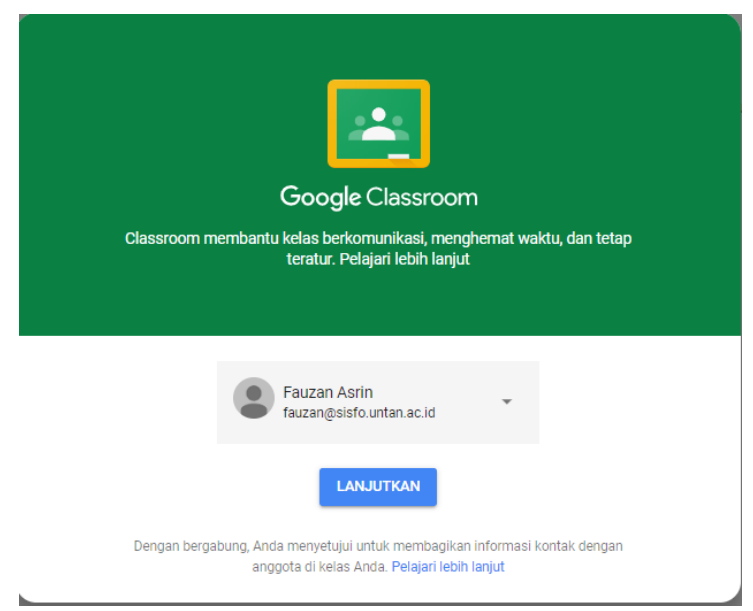

Sumber: https://classroom.google.com/u/3/h

Gambar 2. Tampilan Laman Google pada Langkah Awal Pembuatan Google Classroom

Setelah mengklik lanjutkan, maka pilih peran pengajar sebagai seorang pengajar baik guru, dosen dan pendidik lainnya.

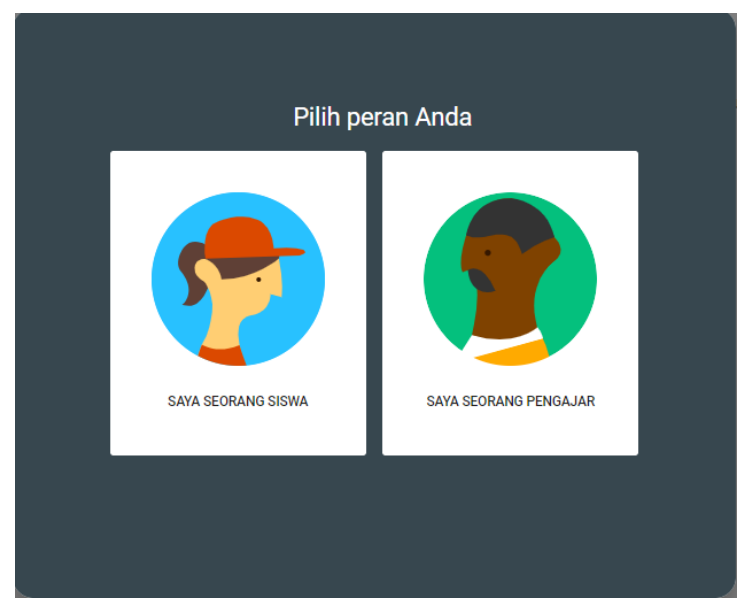

Sumber: https://classroom.google.com/u/3/h

Gambar 3. Tampilan Laman Peran Pada Google Classroom Pada Langkah ke Dua Pembuatan Google Classroom

Setelah memilih peran sebagai seorang pengajar langkah selanjutnya yaitu, klik menu $(+) \rightarrow$ lalu buat kelas seperti pada Gambar 4.

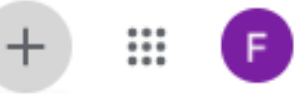

\section{Gabung ke kelas}

\section{Buat kelas}

Sumber: https://classroom.google.com/u/3/h

Gambar 4. Tampilan pembuatan kelas langkah ketiga.
Setelah mengklik "Buat kelas" maka akan muncul kotak dialog sebelum menggunakan kelas. Pada kotak dialog terdapat kotak kecil yang harus dicentang, kemudian klik lanjutkan. Setelah itu akan muncul tampilan seperti Gambar 5. Isi form sesuai kebutuhan, kemudian klik "buat" untuk melanjutkan.

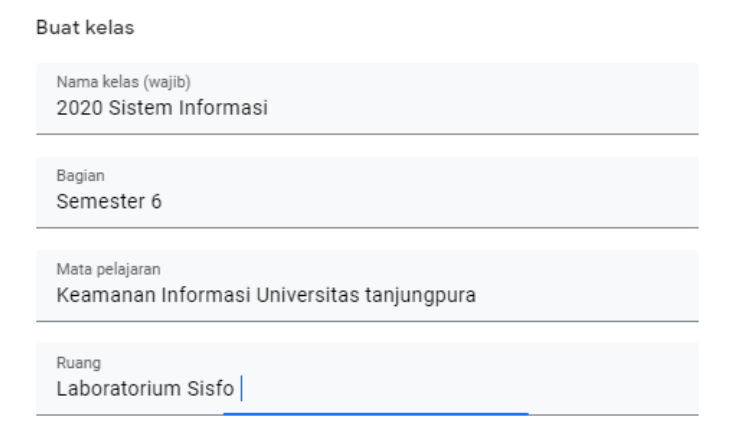

Sumber: https://classroom.google.com/u/3/h

Gambar 5. Tampilan Form Pembuatan Kelas Langkah Keempat.

Setelah dibuat maka akan muncul halaman baru yang berisi fitur google classroom seperti Gambar 6.

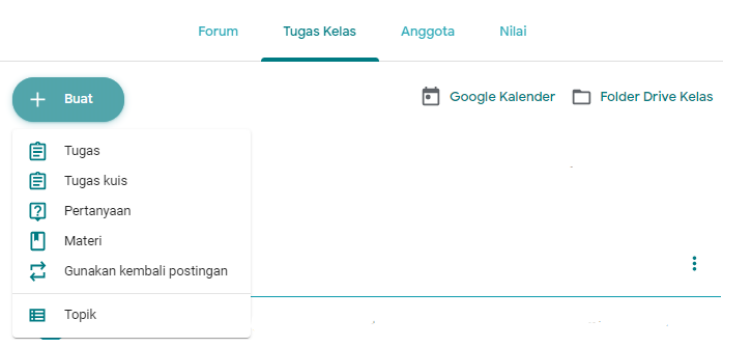

Sumber:

https://classroom.google.com/u/0/w/NjQ3MjU4Nzg4NTVa/t lall

Gambar 6. Tampilan fitur google classroom

. Keterangan dari Gambar 6 adalah

sebagai berikut:

1. Forum

Merupakan Fitur yang ditawarkan classroom sebagai media interaksi antara pendidik dan peserta didik. Ketika pendidik membagikan bahan ajar, tugas, pengumuman maupun 
pertanyaan maka akan muncul pemberitahuan di forum tersebut seperti yang ditunjukkan pada Gambar 7.

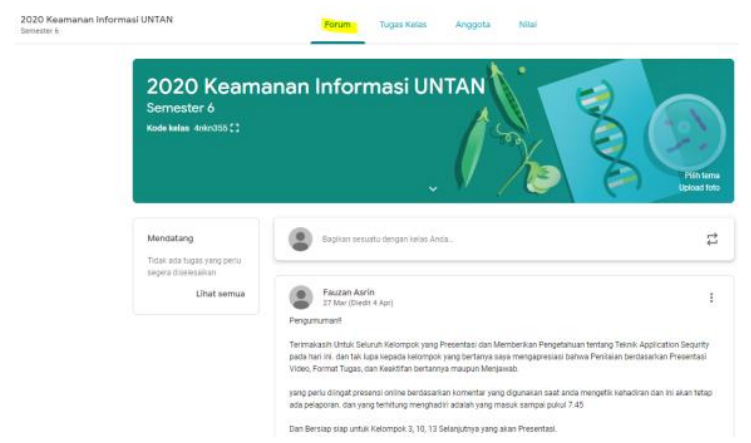

Sumber:

https://classroom.google.com/u/0/c/NiQ3MiU4Nzg4NTVa

Gambar 7. Tampilan Fitur Forum Google Classroom

\section{Anggota}

Pada fitur ini, pemilik akun dapat melihat jumlah anggota termasuk pengajar dan peserta didik, dan pengajar juga dapat menambahkan anggota kelas baik pengajar maupun peserta didik dengan memasukkan username e-mail peserta didik.

\section{Google Calender}

Pengajar dapat membuat jadwal kelas sesuai kesepakatan kelas.

\section{Folder Drive Kelas}

File-file yang sudah diupload akan tersimpan dalam google drive yang sewaktu-waktu dapat dibagikan.

5. Tugas

Fitur ini untuk membagikan tugas, baik berupa gambar, teks, audio, maupun video presentasi.

6. Tugas Kuis

Pengajar dapat membuat kuis dengan bantuan google form yang ada, baik berupa pilihan ganda maupun essay. Selain itu, fitur ini juga disertai dengan informasi tenggat waktu, sehingga ketika peserta didik sudah mengerjakan tugas, maka sistem akan mencatat waktu secara otomatis dalam pengumpulan tugas oleh peserta didik dan pendidik bisa melihat status pengumpulan tugas peserta didik, terlambat atau tepat waktu. Selanjutnya, pengajar dapat memberikan penilaian terhadap tugas yang dikerjakan oleh peserta didik.

7. Pertanyaan

Pengajar dapat membuat pertanyaan secara online dan masing-masing peserta didik dapat memberikan jawaban terhadap pertanyaan tersebut.

8. Materi

Pada fitur ini, pengajar dapat membagikan bahan ajar baik berupa gambar, teks, audio, maupun video presentasi sesuai dengan Gambar 7 berikut.

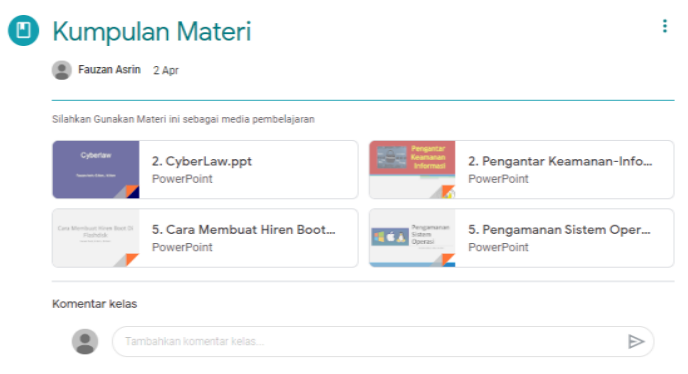

Sumber:

https://classroom.google.com/u/0/c/NjQ3MjU4Nzg4NTVa/ m/NjY1MTY0NDM4ODla/details

Gambar 8. Tampilan Fitur Materi Google Classroom.

Langkah-langkah mengupload materi

dijelaskan sebagai berikut.

1) Isi judul, kemudian pilih topik (bahasan) sesuai dengan materi.

2) Isi bahan ajar dengan beberapa fitur seperti yang ditunjukkan pada Gambar 6 yang diberi kotak berwarna merah. Berikut penjelasannya:

a) Fitur untuk mengupload file pada perangkat pengajar (komputer/laptop/smartpho 
ne), dapat berupa Microsoft Word, Power Point, atau media lainnya.

b) Fitur ini untuk menambahkan file yang sudah terupload di google drive.

c) Pada fitur ini, pengguna dapat menyisipkan video dari youtube dengan cara menyalin url youtube.

d) Fitur ini merupakan tempat untuk menyalin link dari berbagai sumber/referensi.

3) kemudian klik "posting". Untuk memberikan informasi kepada peserta didik.

9. Gunakan kembali postingan fitur ini untuk merepost kembali postingan yang sudah diupload.

10. Topik

Berupa pokok bahasan sesuai materi yang di ajarkan.

Pemanfaatan google classroom di tengah wabah pandemi covid 19 ini memberikan edukasi kepada seluruh pengajar bahwa kemajuan teknologi komunikasi dan informasi dapat membantu pengajar dalam proses belajar mengajar jarak jauh atau daring dengan efektif dan efisien.

Google classroom adalah sistem manajemen pembelajaran yang di tawarkan oleh google untuk pendidik. Aplikasi ini menyediakan lokasi sentral untuk berkomunikasi dengan peserta didik, mengajukan pertanyaan, dan membuat tugas (Maharani \& Kartini, 2019).

Google classroom adalah solusi yang dapat digunakan bagi para pengajar di tengah wabah covid 19 ini sebagai fasilitas gratis pembelajaran online untuk peserta didik di era milenial sekarang. Selain itu, google classroom memiliki potensi untuk menghemat sebagian besar waktu bagi peserta didik dan pengajar karena proses menyiapkan google classroom sangat cepat dan nyaman untuk digunakan. Waktu tidak akan terbuang sia-sia untuk mendistribusikan dokumen fisik karena tugas yang telah diberikan kepada peserta didik oleh pengajar dapat diselesaikan tepat waktu secara online. Hal tersebut membuat kendala waktu yang kurang ketika pembelajaran tatap muka berlangsung dapat teratasi.

Keberadaan google classroom ini menjawab perkembangan industri revolusi 4.0 di Indonesia di bidang pendidikan bahwa Indonesia siap untuk menyambut perkembangan teknologi informasi dan komunikasi diawali dari dunia pendidikan.

\section{KESIMPULAN}

Pemanfaatan media online google classroom mempunyai dampak penting bagi pembelajaran di tengah wabah covid 19 yang tersebar di Indonesia, antara lain: pembelajaran dilakukan secara daring dan mendukung kebijakan pemerintah untuk physical distancing. Dengan memanfaatkan teknologi komunikasi dan informasi, tidak ada perbedaan hasil belajar mahasiswa setelah diajar dengan menggunakan media pembelajaran google classroom, tidak ada pembatasan baik ruang maupun waktu sehingga bisa dilakukan dalam waktu tempat yang di inginkan, peserta didik terlibat secara langsung dalam proses pembelajaran yang memanfaatkan jaringan internet, materi pembelajaran mudah di akses, menumbuhkan dan melahirkan semangat literasi data dan literasi teknologi komunikasi dan informasi. Pembuatan google classroom dapat dilakukan secara mudah oleh pengajar baik guru maupun dosen di pendidikan tinggi 
dengan tujuan mendukung kebijakan pemerintah terkait belajar di rumah dalam penyebaran virus Corona 19 secara massif di Indonesia. Penyebaran virus corona secara massif dapat memutus mata rantai penyebaran dengan memanfaatkan media daring google classroom.

\section{REKOMENDASI}

Sesuai dengan kebijakan
pemerintah dalam mengatasi
penyebaran secara masif pandemi
virus corona 19, pembelajaran tetap
dapat dilakukan oleh pengajar dan
peserta didik, karena mereka dapat
melaksanakan proses belajar dan
mengajar interaktif di rumah dengan
memanfaatkan teknologi informasi dan
komunikasi secara daring.

\section{UCAPAN TERIMA KASIH}

Penelitian ini dapat tersusun dengan baik berkat bantuan berbagai pihak. Peneliti mengucapkan terimakasih kepada pihak-pihak yang tidak dapat disebutkan satu persatu dan mendukung dalam tersusunnya penelitian ini. Tidak lupa peneliti ucapkan terimakasih untuk Badan Penelitian dan Pengembangan Provinsi Kalimantan Barat yang telah bertindak sebagai fasilitator dalam penerbitan jurnal ini.

\section{DAFTAR PUSTAKA}

El Fauziah, U. N., Suryani, L., \& Syahrizal, T. (2019). Penerapan Google Classroom Dalam Pembelajaran Bahasa Inggris Kepada Guru-Guru Bahasa Inggris Smp Di Subang. Abdimas Siliwangi, 2(2), 183. https://doi.org/10.22460/as.v2i2p1 83-191.3281

Hakim, A. B. (2005). Efektifitas Penggunaan ELearning Moodle. Google Classroom Dan Edmodo. In Jurnal I-Statement Stimik ESQ (Vol. 1, Issue 2, pp. 1-6).
Hammi, Z. (2017). Implementasi Google Classroom Pada Kelas Xi Ipa Man 2 Kudus. 87.

Maharani, N., \& Kartini, K. S. (2019). Penggunaan google classroom sebagai pengembangan kelas virtual dalam keterampilan pemecahan masalah topik kinematika pada mahasiswa jurusan sistem komputer. PENDIPA Journal of Science Education, 3(3), 167-173. https://doi.org/10.33369/pendipa.3 .3.167-173

Nirfayanti, N., \& Nurbaeti, N. (2019). Pengaruh Media Pembelajaran Google Classroom Dalam Pembelajaran Analisis Real Terhadap Motivasi Belajar Mahasiswa. Proximal, 2(1), 50-59. https://doi.org/https://doi.org/10.30 605/2615-7667.211

Nurfalah, E. (2019). Optimalisasi ELearning berbasis Virtual Class dengan Google Classroom sebagai Media Pembelajaran Fisika. Physics Education Research Journal, 1(1), 46. https://doi.org/10.21580/perj.2019. 1.1.3977

Sabran, \& Sabara, E. (2019). Keefektifan Google Classroom sebagai media pembelajaran. Diseminasi Hasil Penelitian Melalui Optimalisasi Sinta Dan Hak Kekayaan Intelektual, 122125.

Soni, Afdhil Hafid, Regiolina Hayami, Yulia Fatma, Febby Apri Wenando, Januar Al Amien, Evans Fuad, Mitra Unik, Harun Mukhtar, H. (2018). Optimalisasi Pemanfaatan Google Classroom Sebagai Media Pembelajaran Di Smk Negeri 1 Bangkinang. Jurnal Pengabdian Untuk Mu NegeRl, 2(1), 17-20.

Susanti, L. (2015). Hubungan 
Penggunaan Google Classroom Sebagai Pembelajaran Efektif Dan Paperless Terhadap Nilai Hasil Belajar Kognitif Pada Pelajaran

Biologi Di Sma Charis- Malang. 253258.

Undang-undang Nomor 20 Tahun 2003 tentang Sistem Pendidikan Nasional

Wicaksono, V. D., \& Rachmadyanti, P. (2016). Pembelajaran Blended Learning melalui Google Classroom di Sekolah Dasar. Seminar Nasional Pendidikan PGSD UMS \& HDPGSDI Wilayah Timur, $\quad$ 513-521. http://hdl.handle.net/11617/9144 